\title{
Investigating the Depth and the Geometry of the Quarzitic Panafrican Basement Using Near-Surface 3D Seismic Refraction Tomography: Case Study of the Locality of Bakel (Senegal)
}

\author{
Mapathe Ndiaye, Oustasse Abdoulaye Sall, Alassane Thiam, Déthié Sarr, \\ Moustapha Badji, Issa Ndoye \\ Laboratory of Mechanics and Modeling, Faculty of Engineering, University of Thies, Thies, Senegal \\ Email: mapathe.ndiaye@univ-thies.sn
}

How to cite this paper: Ndiaye, M., Sall, O.A., Thiam, A., Sarr, D., Badji, M. and Ndoye, I. (2020) Investigating the Depth and the Geometry of the Quarzitic Panafrican Basement Using Near-Surface 3D Seismic Refraction Tomography: Case Study of the Locality of Bakel (Senegal). International Journal of Geosciences, 11, 345-359. https://doi.org/10.4236/ijg.2020.116018

Received: March 12, 2020

Accepted: June 6, 2020

Published: June 9, 2020

Copyright $\odot 2020$ by author(s) and Scientific Research Publishing Inc. This work is licensed under the Creative Commons Attribution International License (CC BY 4.0).

http://creativecommons.org/licenses/by/4.0/

(c) (i) Open Access

\begin{abstract}
Seismic refraction investigations have been carried out in Bakel, Eastern Senegal. The purpose was to map geometrical relationship between the existing rock types and the Panafrican quarzitic basement, which is valuable information for the project of the Bakel fluviatile port construction. Four seismic refraction profiles were acquired. The obtained data have been processed by inversion. The obtained four seismic P-wave velocity profiles have been integrated to obtain a 3D model. By comparing the outcropping geological formations with the observed seismic data at the surface, it was possible to identify the lithology corresponding to each measured range of seismic velocity for the alluvium, the weathered bed rock, and the fresh rock. The results showed that the depth of the fresh rock of the basement varies from 0 to 18 meters above the sea level, with a deepening toward the Senegal River and toward the Northern part of the studied area. The presence of alluviums and their thickness are linked to the existence of bays and gulfs. The results of this study give valuable information for the river bed dredging cost assessment prior to the port construction phase.
\end{abstract}

\section{Keywords}

Panafrican, Alluvium, Quartzite, Seismic Refraction Tomography, 3D Model, Bakel, Senegal 


\section{Introduction}

The Geology of Senegal shows a sedimentary basin covering more than $90 \%$ of surface of the Country. The formations of the sedimentary basin have ages ranging from Maastrichtian to Early Miocene upon which, we have recent Quaternary sedimentary formations [1]. Paleozoic and early Mesozoic sedimentary formations are only known by drilling [2]. These sedimentary formations lay down on a Cambrian to Precambrian basement shallowing up from West to East. Therefore, the formation of the basement outcrops on the Eastern part of Senegal, mainly from Bakel, to the Guinean and Malian frontiers [3].

This repartition of the geological formations describes also a varying topography decreasing mainly from East to West. This topography allows to the Senegal River to flow in the same direction, from its source in Guinea to the North of Saint Louis, in the vicinity of the Atlantic Ocean, Western Senegal (Figure 1). The Senegal River has a course of $1790 \mathrm{~km}$. It started in Guinea and delineates the frontiers between Senegal and Mali on its Eastern section, and between Senegal and Mauritania in its Northern part [4].

Due to the international course of Senegal River (Figure 1), the crossed States (Guinea, Senegal, Mali and Mauritania) set up an intergovernmental organization to manage the River. The organization is responsible of managing the watershed of the Senegal River. This includes several damns built on the River for

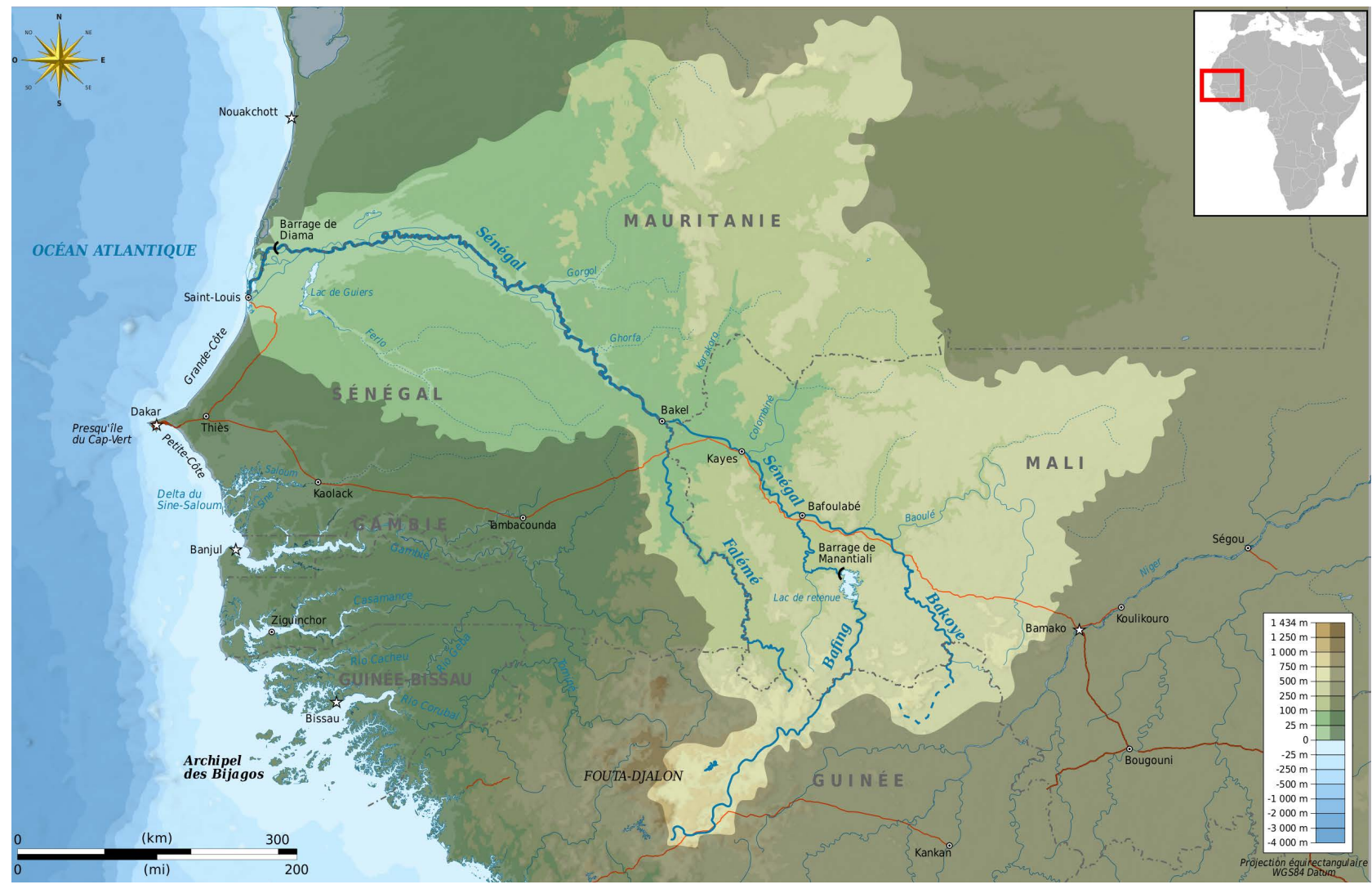

Figure 1. Geographical situation of the Senegal River watershed. We can see the Senegal river organization member States: Guinea in the South, Mali in the East, Mauritania in the North and Senegal in the West. 
hydroelectricity production and for sharing water for drinking and agriculture between the member States [5]. Another responsibility of the organization is to enhance and maintain navigability on the Senegal River [6] [7].

To enhance navigability on the Senegal River and to enhance regional integration and cooperation, it has been planned since a while, to build a port at the locality of Bakel. Bakel is located in Senegal. Nevertheless, it forms a triple point between Mali, Senegal and Mauritania. Its geographical position makes of Bakel a good candidate for building an international port, benefiting to as many member States as possible. Therefore, investigating the lithology and the geometry of the basement will provide, additionally to the geological knowledge of the Panafrican basement, valuable information in the preliminary design phase of the Port.

It is well known and established that the basement is outcropping when we move towards Bakel in the East. Subsequently the basement will be shallowing up toward this direction. Several studies have been performed in the aim to map the depth of the basement [8] [9] [10] [11], nevertheless, the scale and the resolution of these studies were not high enough to provide sufficient information on the thickness of the sedimentary layer along the Senegal river course.

The aims of this study is to map at a high resolution, in the locality of Bakel, the geometric relationship between alluviums, under the Senegal river bed, and substratum, to assess the hardness of the rocks present underground using a geophysical investigation method, more specifically seismic refraction tomography technique which gives the underground repartition of seismic $\mathrm{P}$-wave velocities.

\section{Geological Setting}

The site of this study is located in Bakel, Eastern Senegal. Bakel is on the frontier between the Meso-cenozoic Senegalo-mauritanian sedimentary basin. It corresponds to the outcropping of the Proterozoic basement, locally represented by the Panafrican Mountain chain [3]. The Panafrican chain is also referred to as Mauritanides. The Mauritanides have been successively affected by the Panafrican orogeny (1000 to $595 \mathrm{Ma}$ ) and the Hercynian orogeny dated between 300 and $250 \mathrm{Ma}[8][12]$.

The Mauritanides is a thrust belt long of $2000 \mathrm{~km}$ surrounding the West African Craton [13]. It includes three main parts: the Adrar Soutouf Massif in Southern Morocco [14], the Central Mauritanides in Mauritania, starting from Bakel in Senegal to Southern Morocco referred to as Anti-Atlas [15], the Bassarides Belt in the Northern Guinea and Southern Senegal [10] and the Rokelides Belt from Guinea to Liberia [16] [17].

At Bakel, the Mauritanides is locally represented by formations referred to as the "Group of Bakel" belonging to the "Complex of Bakel". The Complex of Bakel is a thrust zone formed of several groups of meta-volcanic and meta-sedimentary allochthones units. In fact, the Group of Bakel overlaps allochthone units in the East and is overlapped from the West [18]. 
The "Complex of Bakel" shows several hills around Bakel. The hills are formed of schists showing inclusions of sericite or hematite and reinforced with quarzitic bars.

The thrust belt formations described above present local plains occupied by Holocene alluvial deposits linked to the regime of the Senegal River and/or its tributaries [19]. More details about the structure of the Mauritanides thrust belt in the vicinity of Bakel and the studied area can be found on the geological map (Figure 2).

\section{Materiel and Methods}

The geometric relationship of the rock types around the Senegal River bed in the site of study, the alluvium layer, the weathered bedrock and the depth of the fresh hard bedrock has been investigated using 4 seismic refraction profiles (Figure 3). In fact, seismic investigation techniques are widely used in soil mechanical properties studies, particularly in rippability or ease of excavation assessment of rocks which is a significant aspect of the preliminary work of any civil engineering project [20] [21] [22] [23]. Seismic Refraction is a cost effective powerful investigation tool for shallow survey, and is increasingly used for small scale mapping of near surface, particularly in site investigations for civil and geotechnical engineering [24]. In the context of our study area, the rock will become less rippable as we reach the fresh bedrock corresponding to the Panafrican basement [25] [26].

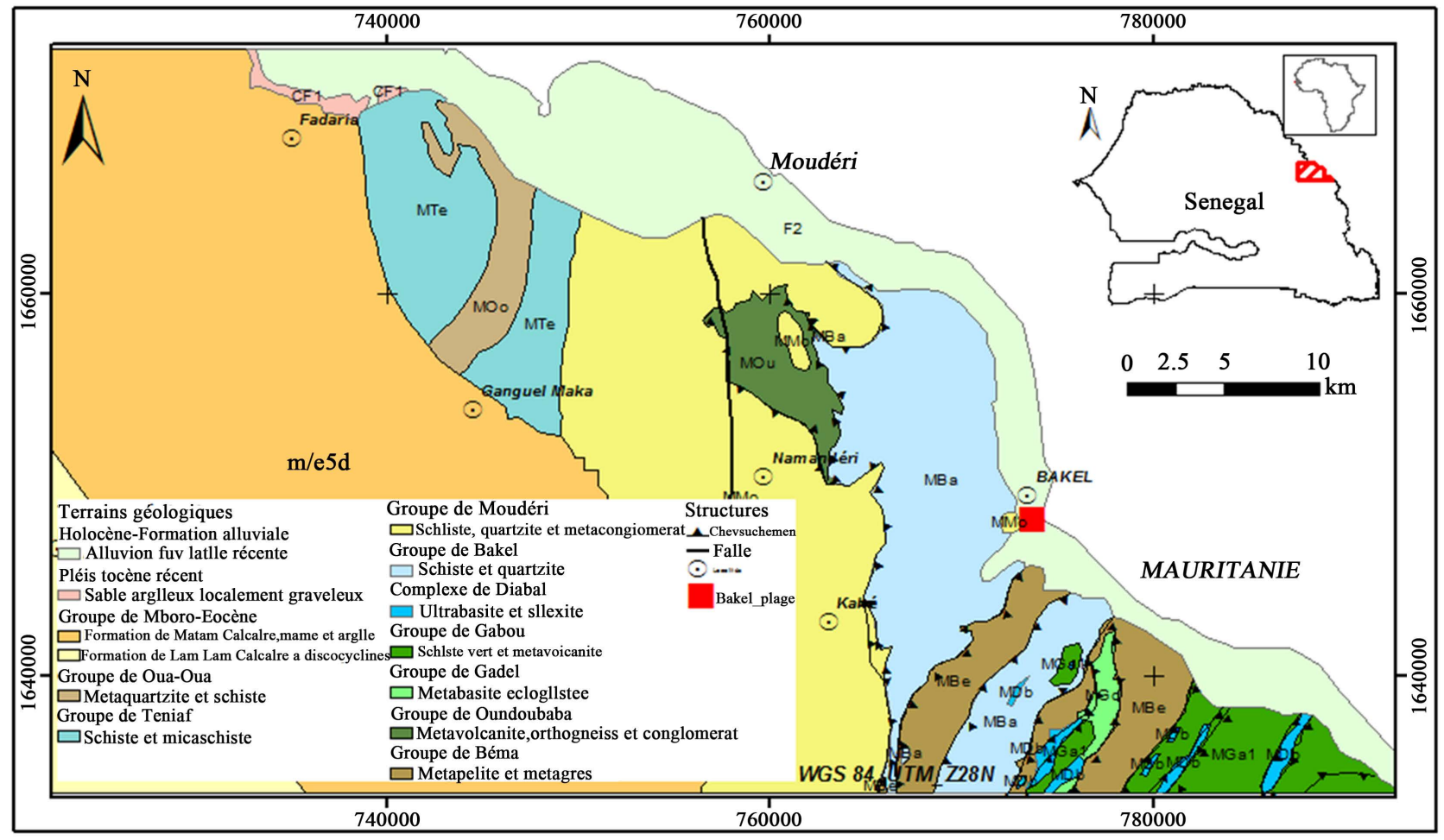

Figure 2. Geological map of the eastern part of Senegal showing the Mauritanides thrust belt around Bakel and its main complexes and groups. The investigated site is represented by the red square [18], modified. 


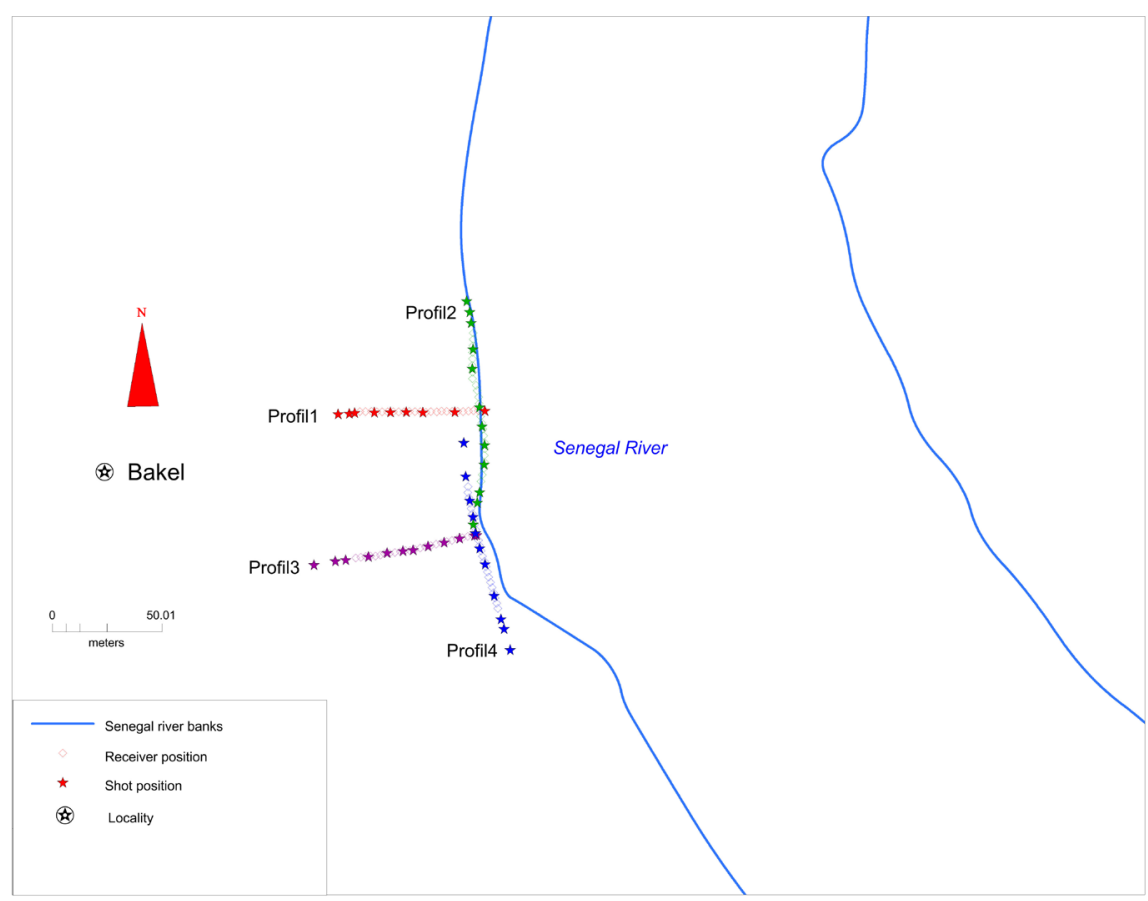

Figure 3. Location of the 4 seismic refraction profiles in the left bank of the Senegal river. Around the investigated area, the shoreline of the River is bending sharply forming a gulf in the Southern part followed by a bay in the North.

Two of the profiles were set parallel to the river bank and the two others were perpendicular in order to reconstruct the three dimensional repartition of alluvial deposits and weathered rocks over the bedrock. The length of the profiles varies from 50 to $70 \mathrm{~m}$ allowing to reach approximate depth of investigation from 15 to $25 \mathrm{~m}$ respectively. The length of the profiles was driven by the landcover constraints. In fact, the study site is bordered in the West by the City of Bakel, and in the East by the river. Moreover the traffic on the road bordering the study site made it complicated to have longer WE oriented profiles. This situation resulted in river parallel profiles longer than perpendicular ones limited by the extend and the human activities of Bakel City. Nevertheless, the obtained profiles length, which controls the depth of investigation was enough to achieve the targeted depth of investigation that was 15 to 20 meters.

For the different profiles, the receiver spacing varies between 2.5 and $5 \mathrm{~m}$ to achieve a good resolution.

We used a 24 channels Daqlink III seismograph with a set of $10 \mathrm{~Hz}$ geophones. The data acquisition parameters for gain, sampling rate and time window were set respectively to $1,0.125$ millisecond and 0.5 second. The seismic source, was an $80 \mathrm{~kg}$ mass dropped by an electric motor from 2 meters height on a plate fixed on the soil. For each profile, 11 shots were performed consisting of 4 offset shots, 2 end shots, 4 internal shots (between geophones 3 - 4, 6 - 7, 18 $19,21-22)$ and 1 center shot between geophones 12 and 13. For more accurate results, the coordinates for the sources and receivers were collected using a Leica differential GPS. 
The first arrivals have been picked on each shot of the acquired seismic refraction data under Vibrascope which was also used as acquisition software (Figure 4). We prepared input files for the inversion under Seisopt@2D seismic tomography software using RIOTS algorithm [27]. The three input files for the inversion software consist of:

- The source file, containing the coordinates of all the shots for a given profile. For a given profile and for each shot the position (x), the altitude (z) and the number of receivers $(\mathrm{N})$ are specified.

- The receiver file, containing for each shot, the position (x) and the altitude (z) of each of the 24 geophones.

- The picking file, containing for each shot, the time of first arrival for each receiver.

The inversion parameters and the quality control of the output model were tuned mainly by comparing observed and predicted hodochrons (Figure 5).

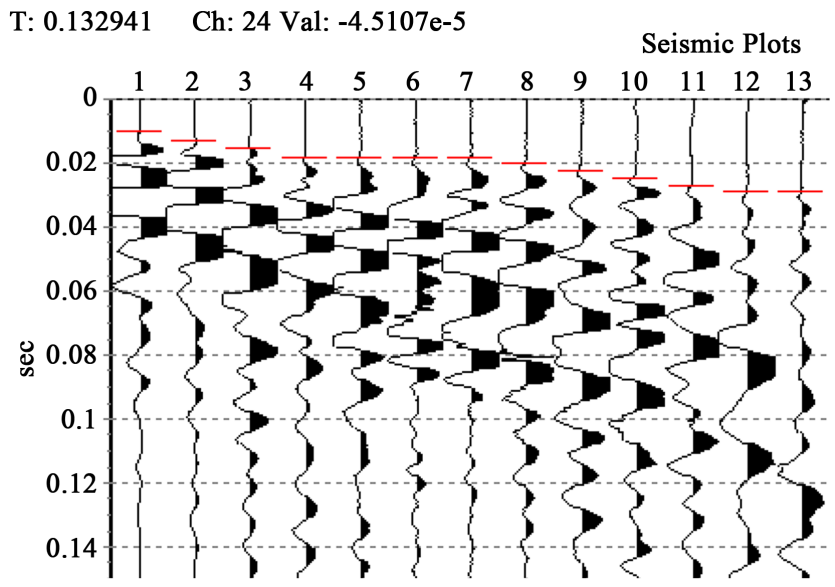

Figure 4. Picking of first arrivals for each seismic refraction shot under Vibrascope.

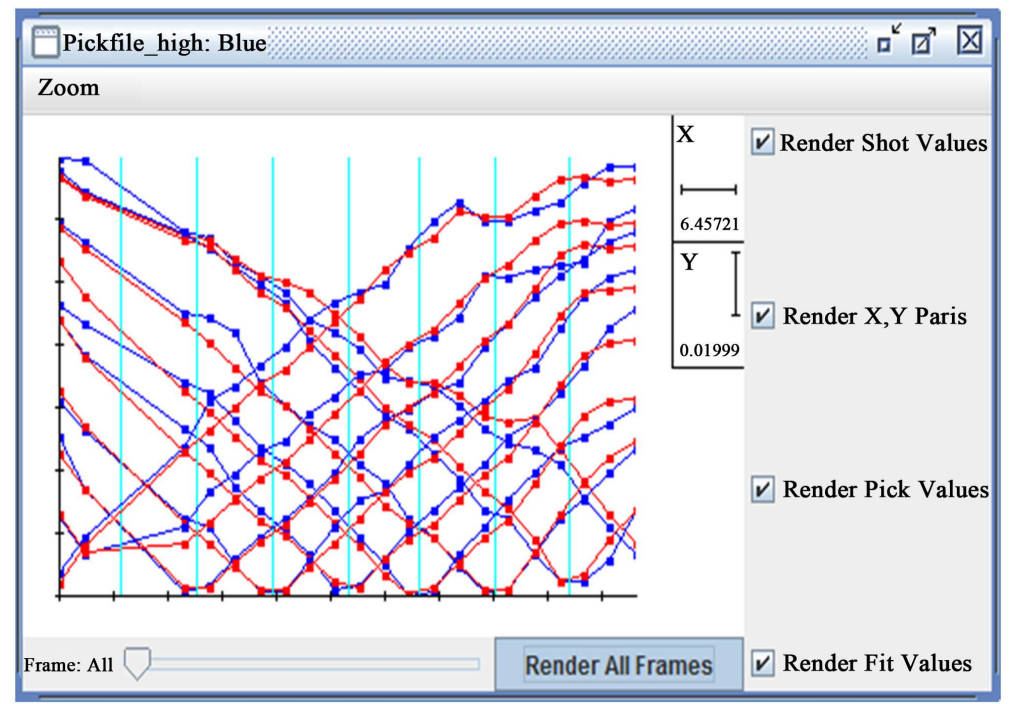

Figure 5. Comparing observed and predicted hodochrons under Seisopt@2D inversion software. 
The inversion produced four seismic $2 \mathrm{D}$ profiles showing P-wave velocity variation with depth (Figure 8). Even if the 2D profiles show spatial change of the seismic $\mathrm{P}$ wave velocity with depth, they do not allow understanding easily their geometrical relationship and the tridimensional geometry of the bedrock and the overlaying alluvium. To integrate the $2 \mathrm{D}$ profiles into a tridimensional model, we computed a 3D block model using the Rockware Rockworks ${ }^{\circledast}$ software.

The obtained 3D block model allows a better comprehension of the geometry of the existing geological formations. And to achieve a major goal of the study which consists of identifying the different types of lithology, we need to interpret the seismic $\mathrm{P}$ wave velocity to rock type. The interpretation of seismic velocity to rock type was done based on the outcropping rocks along the seismic profiles and confirmed using Caterpillar rippability chart [28] presented below (Figure $6)$.

The main steps of our approach are summarized in the flow diagram below (Figure 7).

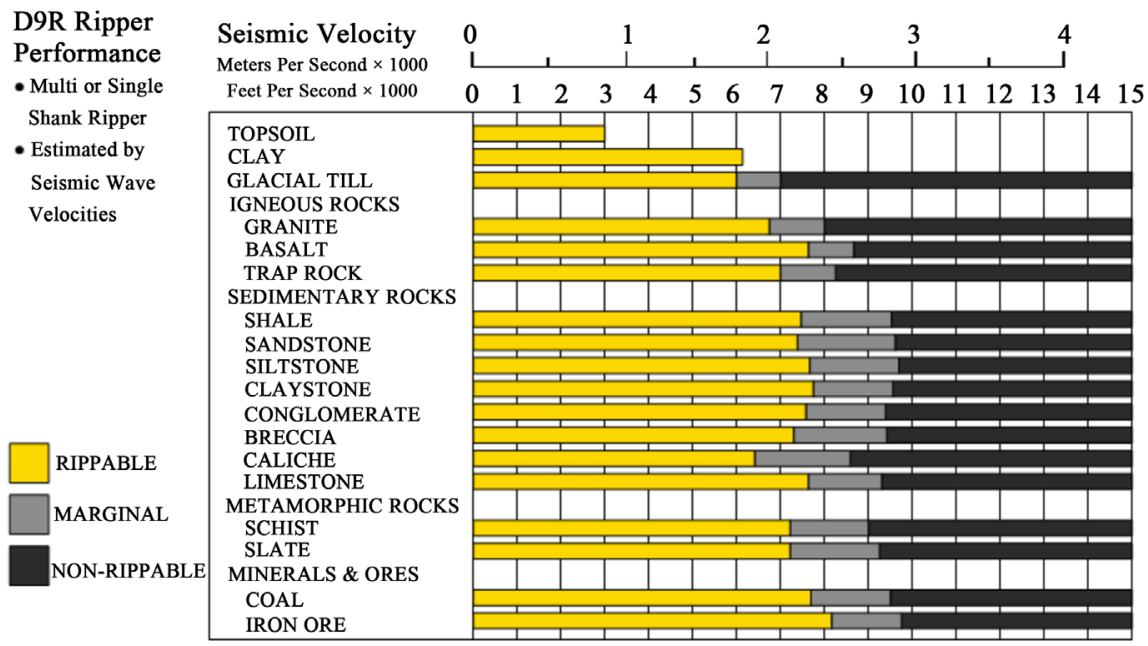

Figure 6. Example of a caterpillar rippability chart for the D9R ripper [28].

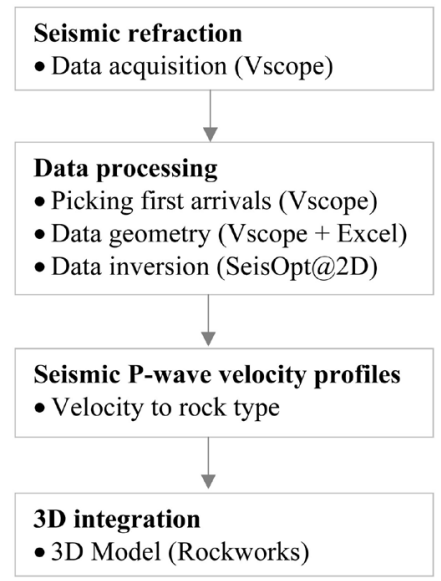

Figure 7. Flow diagram of the main step of the methodology. 


\section{Results and Discussion}

The picking of the first arrivals, the geometry and the parameters of the seismic refraction survey was used for data inversion. Inversion allowed to reconstruct the seismic velocity model from the observed data [29]. The inversion of the seismic refraction data resulted in 4 seismic profiles showing the repartition of P-wave velocity with depth (Figure 8).

The obtained results show that the measured seismic P-wave velocities vary from 290 to $5200 \mathrm{~m} / \mathrm{s}$. All the four profiles show increasing velocity with depth. The comparison of seismic velocity repartition with outcropping geological formations allows to deduce that alluvium, in the upper layer, shows lower velocities and the fresh and hard rock shows higher velocities. The transition between the velocities of alluvium and hard rock is formed by the weathered rock.

To determine the lithology from the obtained seismic tomography profiles, we used information from the outcropping rocks in the study area to convert the P-wave velocity to rock type with the following approach: we consider the three main existing facies: the alluvium, the fresh quartzite and the mixture. The mixture is formed of alluvium containing big blocks or weathered quartzite (Figure 9).

The location A shows a massif of weathered rock passing into its center to hard rock and corresponding to the Southern end (left part) of profile 4 . The measured velocities vary from 1200 to $3200 \mathrm{~m} / \mathrm{s}$ when we moved from weathered to fresh rock.

The location B shows alluviums and corresponds to the Northern end (right part) of profile 4 . The measured velocities vary from 290 to $800 \mathrm{~m} / \mathrm{s}$.

We can deduct from these two observations that the transition between these two intervals, is geologically formed by weathered rocks with velocities varying from 800 to $1200 \mathrm{~m} / \mathrm{s}$. The correlation between seismic P-wave velocities and lithology is summarized in Table 1.

The repartition of the P-wave velocity based on outcropping rocks has been confirmed based on the Caterpillar D9R rippability chart (Figure 6) that slightly consider the same intervals for alluviums, weathered and fresh bedrock based on their rippability.

The obtained seismic velocity data have been compiled to a database containing the UTM WGS84 $\mathrm{x}$ and $\mathrm{y}$ coordinates, the $\mathrm{z}$ level and the velocity. The obtained database has been used to build a block model of the seismic velocity in

Table 1. Types of rocks and corresponding seismic P-wave velocity based on outcropping rocks.

\begin{tabular}{ccc}
\hline Type of rock & Min velocity $(\mathrm{m} / \mathrm{s})$ & Max velocity $(\mathrm{m} / \mathrm{s})$ \\
\hline Alluvium, alluvium mixed with blocks & 290 & 800 \\
Weathered quartzite & 800 & 1200 \\
Fresh quartzite & 1200 & 5200 \\
\hline
\end{tabular}



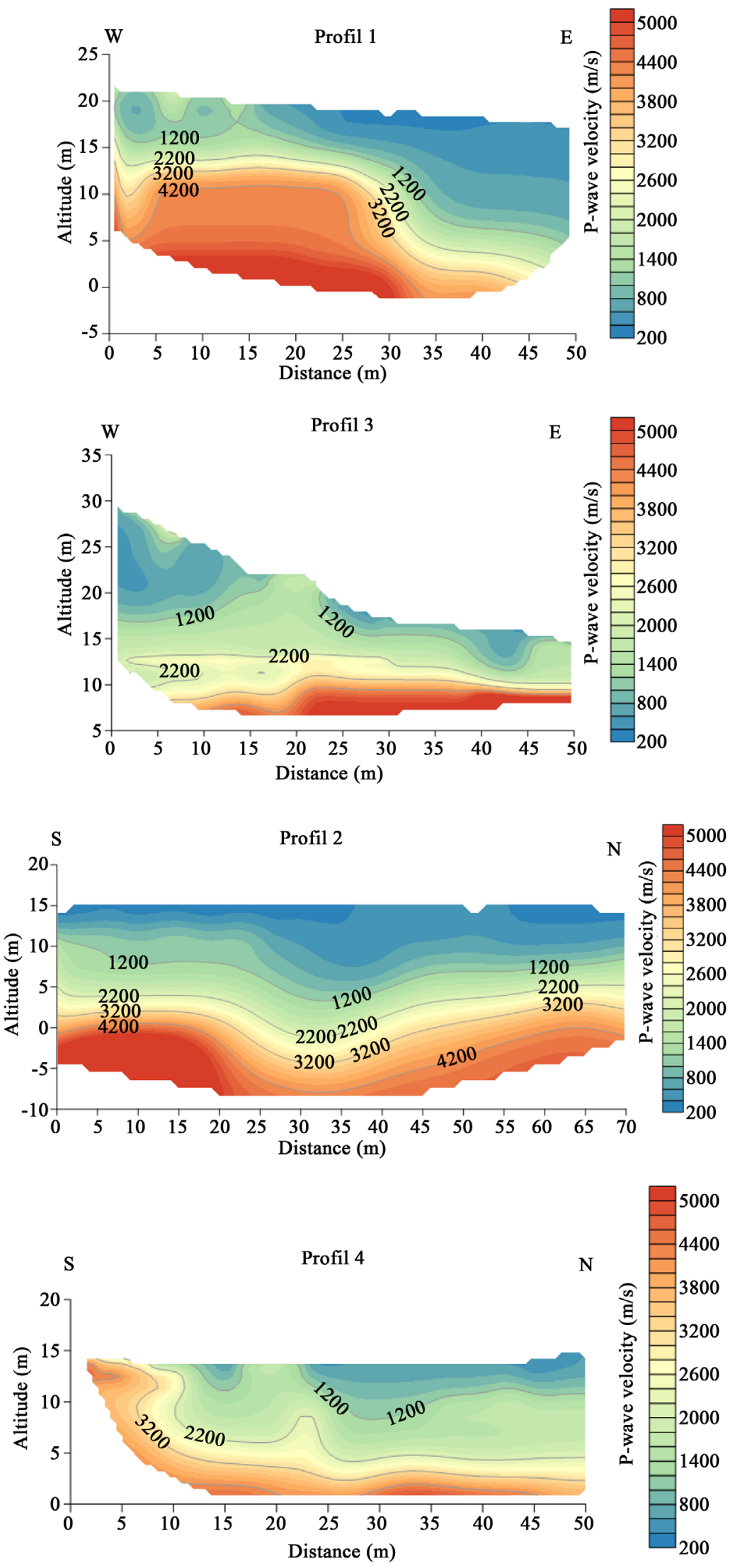

Figure 8. The four seismic profiles showing the variation P-wave velocity with depth. 


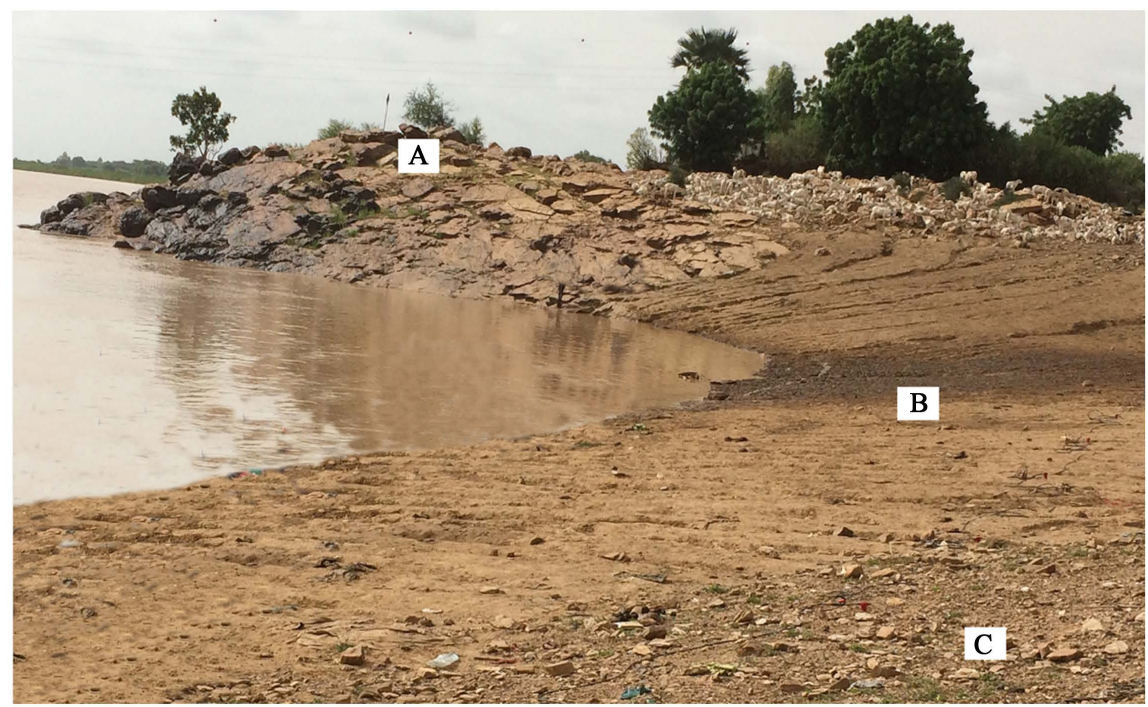

Figure 9. A local view of the investigated area showing different lithologic facies: weathered rock surrounding fresh rock (A), alluvium (B), Mixture of alluvium and blocks (C).

the investigated area. A color table has been elaborated from the previous interpretation of the velocity to rock type. The results of the tridimensional modeling of the data are presented below.

The tridimensional model of the investigated area (Figure 10) shows that the small gulf observed in the Southern part of the investigated area is formed of hard fresh rock passing laterally to weathered rock (Figure 10(a) and Figure $10(c)$ ). The gulf is followed by a bay covered with alluvium (Figure 10(b) and Figure 10(c)). The thickness of the alluvium deposits increases toward the North corresponding to the flowing direction of the Senegal river (Figure 10(a) and Figure 10(d)).

Partly weathered bed rock is obviously present in the transition between the alluviums and the fresh bedrock. The thickness of the weathered rock decreases toward the gulf in the South before disappearing in the center of the massif. Toward the West, the thickness of weathered rock increases when we move far from the river banks.

The fresh bedrock shows an irregular surface, deepening toward the East and the Nord. We can also notice that the maximum depth corresponding to maximum alluvium thickness is obtained in the bay. The deepest point for the bedrock, located in the center of the bay, is at $0 \mathrm{~m}$ above sea level, while the highest point is at $18 \mathrm{~m}$ and is observed on the hills boarding the river. The reference topographic level corresponding to the outcrops of fresh bedrock observed in the massif of the gulf is 14 meters.

The tridimensional model of the investigated area shows that course of the Senegal River is linked to the lithology. In fact, the sharp bending of the river is due to the massif of fresh and partially weathered rock forming a gulf that seems to block the sediments upstream. Right after the gulf, alluviums reappear and let to the river the possibility to shape a large bay downstream. The lithology is in 


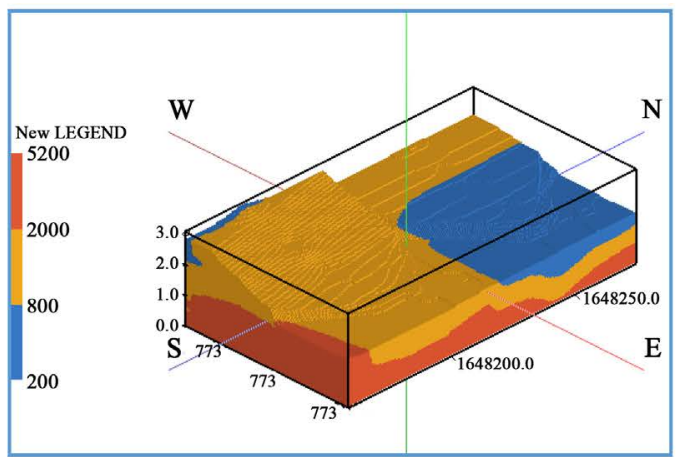

(a)

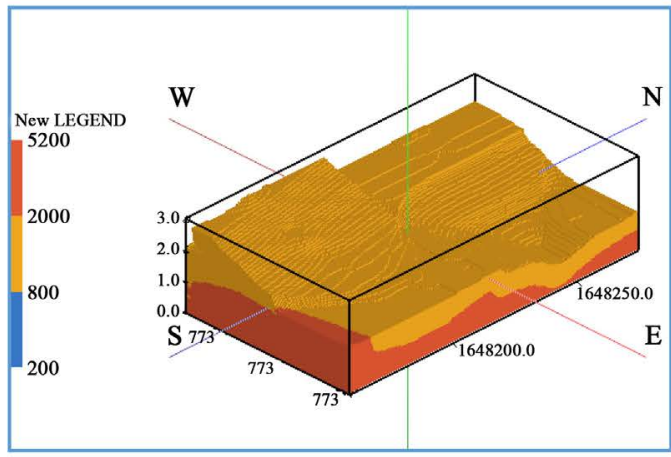

(b)

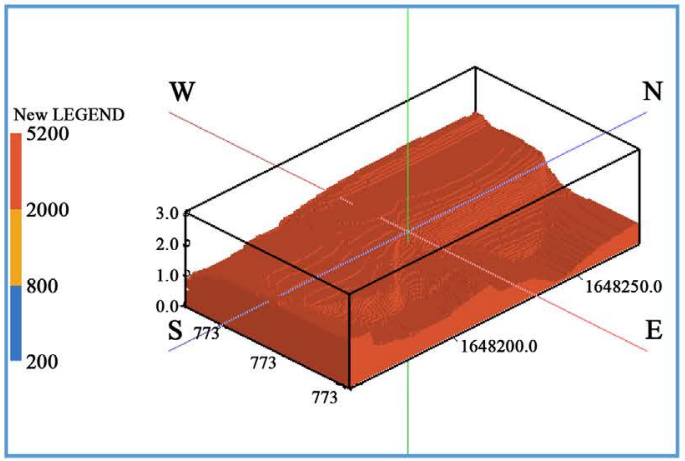

(c)

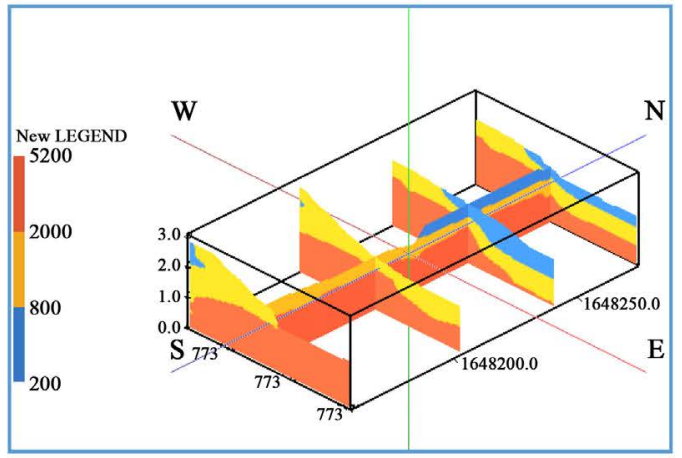

(d)

Figure 10. Tridimensional model of the investigated area and its lithologic interpretation showing the alluvium, the weathered and fresh rock. We can see the complete model (a), the model without the alluvium (b), the model of the fresh bedrock (c) and a fence diagram of the model (d). 
its turn linked to the morphology as, the thickness of the alluvium is very important in the bay and less important in the gulf which corresponds respectively to low and high topography. In fact the sedimentation and erosion rates are controlled by natural and/or anthropic factors [30] [31]. Both erosion and deposition are continuous processes in the river in an attempt to reach a new equilibrium in channel geometry [32]. In the case of the study area, the massif of rock, responsible of the sharp bend of the river dissipates considerably the energy upstream the bay. The barrier formed by the massif seems to be responsible of the decrease of energy that allows more important sedimentation in the bay, while the sharp bending of the river course and the decrease of the depth, induce breaking waves and subsequently important water agitation which cause erosion in the cap.

Moreover, he obtained model allowed estimating the volume of alluvium that could be removed by dredging, in the investigated area which is around 13,000 $\mathrm{m}^{3}$, while the volume of weathered rock is $19,000 \mathrm{~m}^{3}$. The total surface occupied by the model is approximately $7500 \mathrm{~m}^{2}$.

\section{Conclusion and Outlook}

The seismic investigation of the Senegal River banks in the City Bakel gives valuable information on the geometric relationship between the Proterozoic Panafrican basement formed of hard rocks and the overlaying alluvial deposits. Also, to enhance the navigability and insure draught requirements for future boats and vessels navigating in the port, it is necessary to dredge the riverbed. The dredging can involve alluvium, very weathered bed rock that the obtained model can allow to assess and estimate.

The seismic velocity model allows mapping the spatial repartition of the rock types that seem to have a huge influence on the course of the river, the erosion and deposition of the sediments and therefore, their geometry. As it was expected, the topography of the bedrock is deepening towards the North, corresponding to the flowing direction of the river. Finally, the obtained tridimensional seismic P-wave velocity model allows to know that the dredging will be easier toward the North.

The sharp bending and the rapid change in lithology lead to suspect the presence of an EW fault or discontinuity between the gulf and the bay. Further investigations are needed to confirm its presence, its relationship to the geological framework, and eventually its regime, as that can interact with the projected infrastructures. Also, decreasing the spacing between the profiles can increase the resolution and give more accurate repartition of seismic velocities. It is worth to notice that all the profiles were localized onshore; acquiring offshore data can widen the investigated area and give valuable information to Bakel port construction planners. Finally, performing some drills will allow to tune the interpreted model and be more accurate on the lithology corresponding to each measured seismic P-wave velocity. 


\section{Conflicts of Interest}

The authors declare no conflicts of interest regarding the publication of this paper.

\section{References}

[1] Roger, J., Duvail, C., Barusseau, J.P., Noël, B.J., Nehlig, P. and Serrano, O. (2009) Carte géologique du Sénégal à 1/500 000, feuilles nord-ouest, nord-est et sud-ouest. Ministère des Mines, de l'Industrie et des PME, Direction des Mines et de la Géologie, Dakar, 3 coupures.

[2] Ndiaye, M., Ngom, P.M., Gorin, G., Villeneuve, M., Sartori, M. and Medou, J. (2016) A New Interpretation of the Deep-Part of Senegal-Mauritanian Basin in the Diourbel-Thies Area by Integrating Seismic, Magnetic, Gravimetric and Borehole Data: Implication for Petroleum Exploration. Journal of African Earth Sciences, 121, 330-341. https://doi.org/10.1016/j.jafrearsci.2016.06.002

[3] Théveniaut, H., Ndiaye, P.M., Buscail, F., Couëffé, R., Delor, C., Fullgraf, T. and Goujou, J.-C. (2010b) Notice explicative de la carte géologique du Sénégal oriental à 1/500 000. Ministère des Mines, de l'Industrie, de l'Agro-Industrie et des PME, Direction des Mines et de la Géologie, Dakar.

[4] Bruckmann, L. (2017) Les territoires du fleuve: Une analyse par l'image de l'intégration territoriale du fleuve Sénégal. EchoGéo, (42). https://doi.org/10.4000/echogeo.15160

[5] Omvs, H.C. (2007) Projet de gestion des ressources en eau et de l'environnement du bassin du fleuve Sénégal: Composante 3: Analyse Diagnostique Transfrontalière et Plan d'Action Stratégique. OMVS, Analyse Diagnostique Environnementale Transfrontalière du Bassin du Fleuve Sénégal, Synthèse régionale, Rapport final, juin, $139 \mathrm{p}$.

[6] Ndiaye, E.H.M. (2003) Le fleuve Sénégal et les barrages de l'OMVS: Quels enseignements pour la mise en œuvre du NEPAD? VertigO la revue électronique en sciences de l'environnement [Online], Volume 4, Numéro 3.

http://journals.openedition.org/vertigo/3883

https://doi.org/10.4000/vertigo.3883

[7] Tignino, M. (2016) Joint Infrastructure and the Sharing of Benefits in the Senegal and Niger Watersheds. Water International, 41, 835-850. https://doi.org/10.1080/02508060.2016.1214894

[8] Villeneuve, M. (2008) Review of the Orogenic Belts on the Western Side of the West African Craton: The Bassarides, Rokelides and Mauritanides. Geological Society, London, Special Publications, 297, 169-201. https://doi.org/10.1144/SP297.8

[9] Dabo, M. and Aifa, T. (2010) Structural Styles and Tectonic Evolution of the Kolia-Boboti Sedimentary Basin, Kédougou-Kéniéba Inlier, Eastern Senegal. Comptes Rendus Geoscience, 342, 796-805. https://doi.org/10.1016/j.crte.2010.06.002

[10] Villeneuve, M., Theveniaut, H., Ndiaye, P.M. and Retière, S. (2014) Re-Assessment of the Northern Guinean "Koubia-Lessere Unconformity" (KLU): Consequences on the Geological Correlations throughout West Africa. Comptes Rendus Geoscience, 346, 262-272. https://doi.org/10.1016/j.crte.2014.05.004

[11] Diallo, M., Baratoux, L., Dufréchou, G., Jessell, M.W., Vanderhaeghe, O., Ly, S. and Baratoux, D. (2020) Structure of the Paleoproterozoic Kédougou-Kéniéba Inlier (Senegal-Mali) Deduced from Gravity and Aeromagnetic Data. Journal of African 
Earth Sciences, 162, Article ID: 103732. https://doi.org/10.1016/j.jafrearsci.2019.103732

[12] Villeneuve, M., Bellon, H., El Archi, A., Sahabi, M., Rehault, J.P., Olivet, J.L. and Aghzer, A.M. (2006) Evénements panafricains dans l'Adrar Souttouf (Sahara marocain). Comptes Rendus Geoscience, 338, 359-367.

https://doi.org/10.1016/j.crte.2006.02.008

[13] Jessell, M.W., Begg, G.C. and Miller, M.S. (2016) The Geophysical Signatures of the West African Craton. Precambrian Research, 274, 3-24. https://doi.org/10.1016/j.precamres.2015.08.010

[14] Gärtner, A. (2017) Geologic Evolution of the Adrar Souttouf Massif (Moroccan Sahara) and Its Significance for Continental-Scaled Plate Reconstructions since the Mid Neoproterozoic.

[15] Soulaimani, A., Ouanaimi, H., Saddiqi, O., Baidder, L. and Michard, A. (2018) The Anti-Atlas Pan-African Belt (Morocco): Overview and Pending Questions. Comptes Rendus Geoscience, 350, 279-288. https://doi.org/10.1016/j.crte.2018.07.002

[16] Ennih, N. and Liégeois, J.-P. (2008) The Boundaries of the West African Craton. Geological Society of London, London, $533 \mathrm{p}$.

[17] Kwayisi, D., Lehmann, J. and Elburg, M. (2020) The Architecture of the Buem Structural Unit: Implications for the Tectonic Evolution of the Pan-African Dahomeyide Orogen, West Africa. Precambrian Research, 338, Article ID: 105568. https://doi.org/10.1016/j.precamres.2019.105568

[18] Théveniaut, H., Duvail, C., Ndiaye, P.M., Fullgraf, T., Delor, C., Goujou, J.C., Buscail, F. and Diagne, E. (2010) Carte géologique à 1/500 000 du Sénégal, feuille SUD-EST. Ministère des Mines, de l'Industrie, de l'Agro-Industrie et des PME, Direction des Mines et de la Géologie, Dakar.

[19] Nizou, J., Hanebuth, T.J., Heslop, D., Schwenk, T., Palamenghi, L., Stuut, J.B. and Henrich, R. (2010) The Senegal River Mud Belt: A High-Resolution Archive of Paleoclimatic Change and Coastal Evolution. Marine Geology, 278, 150-164. https://doi.org/10.1016/j.margeo.2010.10.002

[20] Smith, H.J. (1986) Estimating Rippability by Rock Mass Classification. The 27 th US Symposium on Rock Mechanics, Tuscaloosa, 23-25 June 1986, 6 p.

[21] McCann, D.M. and Fenning, P.J. (1995) Estimation of Rippability and Excavation Conditions from Seismic Velocity Measurements. Geological Society, London, Engineering Geology Special Publications, 10, 335-343. https://doi.org/10.1144/GSL.ENG.1995.010.01.29

[22] Varughese, A., Dev, H. and Gupta, S.L. (2017) Application of Rippability Characteristics of Sub Surface in Selection of Bridge Site. ISRM India Journal Half Yearly Technical Journal of Indian National Group of ISRM, 6, 30-35.

[23] Ismail, M.A.M., Kumar, N.S., Abidin, M.H.Z. and Madun, A. (2018) Rippability Assessment of Weathered Sedimentary Rock Mass Using Seismic Refraction Methods. Journal of Physics. Conference Series, 995, Article ID: 012105. https://doi.org/10.1088/1742-6596/995/1/012105

[24] Pegah, E. and Liu, H. (2016) Application of Near-Surface Seismic Refraction Tomography and Multichannel Analysis of Surface Waves for Geotechnical Site Characterizations: A Case Study. Engineering Geology, 208, 100-113. https://doi.org/10.1016/j.enggeo.2016.04.021

[25] Goodwin, J., Meixner, T., McAlpine, S. and Nicoll, M. (2016) Estimating Cover Thickness Using Seismic Refraction in the Southern Thomson Orogen-An Uncover Application. ASEG Extended Abstracts, 2016, 1-4. 
https://doi.org/10.1071/ASEG2016ab130

[26] Abdelrahman, K., Alfaifi, H., Ibrahim, E., Al-Qadasi, B. and Alumidan, S. (2017) Detection of a Shallow Groundwater Aquifer Using Seismic Refraction Tomography: A Case Study of Wadi Showat, Abha District, Southern Saudi Arabia. In: SEG Technical Program Expanded Abstracts 2017, Society of Exploration Geophysicists, Tulsa, 5418-5421. https://doi.org/10.1190/segam2017-17738517.1

[27] Optim Inc. (2001) User's Manual SeisOpt@2D Version 2.8. Optim LLC, Boston.

[28] Caterpillar Inc. (2000) Handbook of Ripping. Twelfth Edition, Caterpillar Inc., Peoria, 33 p. http://www.cat.com

[29] Jones, I.F. (2010) Tutorial: Velocity Estimation via Ray-Based Tomography. First Break, 28, 45-52. https://doi.org/10.3997/1365-2397.2010006

[30] Wang, S., Fu, B., Piao, S., Lü, Y., Ciais, P., Feng, X. and Wang, Y. (2016) Reduced Sediment Transport in the Yellow River Due to Anthropogenic Changes. Nature Geoscience, 9, 38-41. https://doi.org/10.1038/ngeo2602

[31] Williams, R.D., Measures, R., Hicks, D.M. and Brasington, J. (2016) Assessment of a Numerical Model to Reproduce Event-Scale Erosion and Deposition Distributions in a Braided River. Water Resources Research, 52, 6621-6642. https://doi.org/10.1002/2015WR018491

[32] Saikia, L., Mahanta, C., Mukherjee, A. and Borah, S.B. (2019) Erosion-Deposition and Land Use/Land Cover of the Brahmaputra River in Assam, India. Journal of Earth System Science, 128, 211. https://doi.org/10.1007/s12040-019-1233-3 